\title{
Miranda
}

Revue pluridisciplinaire du monde anglophone /

Multidisciplinary peer-reviewed journal on the English-

speaking world

$6 \mid 2012$

Marking the Land in North America

\section{Patrizia Di Bello and Gabriel Koureas, Art, History and the Senses-1830 to the Present}

\section{Muriel Adrien}

\section{OpenEdition}

\section{Journals}

\section{Electronic version}

URL: http://journals.openedition.org/miranda/3079

DOI: 10.4000/miranda.3079

ISSN: 2108-6559

Publisher

Université Toulouse - Jean Jaurès

\section{Electronic reference}

Muriel Adrien, "Patrizia Di Bello and Gabriel Koureas, Art, History and the Senses-1830 to the Present", Miranda [Online], 6 | 2012, Online since 28 June 2012, connection on 16 February 2021. URL: http:// journals.openedition.org/miranda/3079 ; DOI: https://doi.org/10.4000/miranda.3079

This text was automatically generated on 16 February 2021.

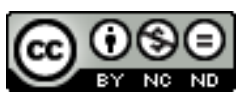

Miranda is licensed under a Creative Commons Attribution-NonCommercial-NoDerivatives 4.0 International License. 


\title{
Patrizia Di Bello and Gabriel Koureas, Art, History and the Senses- 1830 to the Present
}

\author{
Muriel Adrien
}

\section{REFERENCES}

Di Bello, Patrizia, Gabriel Koureas, Art, History and the Senses-1830 to the Present (Farnham : Ashgate, 1996), 199 p, ISBN 9780754668633

1 In the foreword, "Disciplining the Senses: Beethoven as Synaesthetic Paradigm", Simon Shaw Miller starts by saying how the departmental structure of universities have encouraged us to think along disciplinary lines. Drawing on two of Hoffman's texts, one of which is on Beethoven and the other on Johannes Kreisler, Miller says that instrumental music's very invisibility opens the inner eye to richer visions because it is severed from the sensual world and any fixed signification.

2 In their introduction, "Other than the Visual: Art, History and the Senses", Patrizia di Bello and Gabriel Koureas explain how artists from the nineteenth century onwards have increasingly worked outside the realm of sight, and tried to instil into their work a multi-sensuality which is as yet unexplored by art historical analyses. The book covers the period from the beginning of the nineteenth century to the present. They recall Georg Simmel's book which deals with how social and individual identities are also created according to sensory perceptions. Baumgarten (1714-62), who coined the concept of "aesthetics", believed senses partook actively in the semiotic potential of a work. These senses both instinctually perceive the world and resist cultural domestication, and nonetheless construct it culturally for us. The authors stress that the book does not attempt to formulate an overarching theory of art and the senses, but just provides microscopic individual case studies. A panoramic view surveying the field still remains to be done, and would indeed fill a much-needed purpose. 
3 In her chapter, Patrizia di Bello deals with how the first experimental photographers used statues-which do not move by definition-, and connects the reproductive and serial practice of photographs through prints with the multiplication of casts and copies of sculptures to decorate great houses, both indexically preserving the original touch of the artists, and both engaging the viewer in different tactile experiencesalthough museums have been forbidding touching the works of course.

In "Seeing and Tasting the Divine: Simeon Solomon's Homoerotic Sacrament", Dominic James says that Simeon Solomon used the alibi of the Holy Communion as a way to fantasize about homoeroticism under cover of the raising monstrance of the Holy Ghost, with an implicit subtext about men consuming other men. This can be understood when linking various pictures of his, such as one where the holy wafer was substituted by a winged male youth in another painting. He discusses the various pleasures associated with eating in Victorian England and the Catholic apprehension of the Holy Ghost as body of Christ. According to him, Solomon's choice of Catholic rituals was consistent with the way Roman Catholicism was considered by Protestants as tolerant with moral deviance, and their priests seemingly characterized by a want of manliness.

5 Christian Bradstreet's “A Trip to Japan in Sixteen Minutes: Sadakichi Hartmann's Perfume Concert and the Aesthetics of Scent" analyses Hartmann's 16-minute symphony of perfumes (through an apparatus of fans) wafting the audience to Far Eastern exoticism, triggering "smellscapes" or "toposmia" thanks to the potent affect of smell upon the imagination. It resulted in a cacophonic flop because it was staged after musical comedies-which were two incompatible kinds of shows-and because there was no consensual imaginary response to the perfumes. Bradstreet mentions the interest in odour from the 1850s onwards, expressed in painting or in the growing concern about urban pollution and stench, and the subsequent efforts to deodorize the environment. Its amoral bewitching power to induce visions and memories linked it with esotericism. This was yet further evidence that there could be no universal olfactory semantics. Indeed, in the compositional arrangements, Hartmann could not prompt in his audience's mind clear and immediately decodable associations.

6 In "Intimate Modernism: The Nabis, Symbolist Theatre and the Gesamtkunstwerk", Katherine Kuenzli examines the impact that Mallarmé's seminal essay (1885) on Wagner had on the Nabis movement (1889-1900), whose main artists include Edouard Vuillard, Pierre Bonnard, Maurice Denis, Paul Ranson and Paul Sérusier. Even if theirs was an intimate and hermetic art as opposed to the grandiose Wagnerian dramatic performances, the Nabis drew from Wagnerian art their allusive and rarefied arrangements of colour and line, stripped of representational function-whether in domestic environments or in theatrical decors-as a bid to spark auditory and poetic associations.

7 Against the preconceptions of Futuristic art where speed and dynamism are the paramount features, Francesca Bacci argues that noise is the common denominator of Futuristic art. Les Mots en liberté futuristes (1919) features the onomatopeic transcriptions of sounds, typographic collages where the graphic qualities (salience, direction, boldness...) acted as guides for the performer's voice or for the kinaesthesic experience of the viewer. It was in 1910 with Pratella's Manifesto of Futurist Musicians (edited by Marinetti), and more so, later in 1913, with The Art of Noise by Russolo, that Futurism explicitly advocated the incorporation of urban and industrial sounds in 
music (and later, war noises)-all of which inspired Futurist painting. Marinetti also developed "Tattilismo" in 1921 to explore the tactile dimension in painting with physical signifiers, close to or at least contemporary with the hands-on approach of the Montessori method or the didactic material for the visually impaired.

In "Between Sound and Silence: John Cage, Karlheinz Stockhausen and the Sculptures of Dorothea Tanning", Victoria Carruthers explores the confluences between Tanning's three-dimensional rag-doll-limbed sculptures and the equally three-dimensional sounds and silences of Cage's and Stockhausen's works. The formal links between the three artists are unfortunately less convincing than their biographical links. In "Can you hear the lights?", Alexander Dumbadze talks of the much-overlooked droning buzz of Dan Flavin's lights. Although the artist himself denied the importance of the hum, he abandoned the Whitney show, "Light: Object and Image", because of reasons pertaining to the sound of his fellow artist Howard Jones's light works. Although the buzz is not intentionally contrived, it is undeniably part of the physical experience of the work. As such, it questions what the art critic Hal Foster's thought of Flavin's work as creating a kind of two-dimensional, primarily visual pictorial illusionism.

10 In "Niki de Saint Phalle's Hon: An Ethics through the Visual?", Nicola Foster argues that the sheer gigantism of Saint Phalle's Hon prevented the construction of a viewing subject setting the visual object at a distance, thereby challenging the tradition of the reclining nude. Its monumental size referred rather to the primitive and collective. Foster relates the experience to Fried's concept of "literalist art" which suspends objecthood, typified in the dematerialised art forms starting the late 1960s. Juggling with the (fallacious?) idea of objectification and masterly distanced vision, the author runs through a number of theories a little quickly: after Kant and Descartes, she evokes Martin Jay's theory according to which vision and rationality came hand in hand, and are-unfortunately for him-threatened by the critique of contemporary French philosophers. She also mentions Jonathan Crary's argument for whom installation arta physically spatial art-was developed at the same time as the spaceless and dislocated globalized technology. She calls upon Lacan's notion of "the desire of the other's desire" to say that a viewer is entrapped in the experience of the artwork in a fully embodied manner (Niki Saint Phalle's Hon being a case in point), whether the experience be multi-sensorial or not.

11 In his very perceptive article, Jim Drobnick examines various artists' approaches to air conditioning, as "both a contributor and a solution to global warming and rising levels of toxic emissions" (147). Artists challenge the denatured standardized homogenized air quality-imposed by engineering authoritarianism-through the reintroduction of sensory stimulation and ephemeral and volatile air "impurification". Peter Hopkins strategically diffuses fragrances and scents, which can create ambiances that unmoor unknown states of consciousness. Catherine Bodmer's installation "Bounce" (2002-2004) vented the commercial fabric softener supposedly meant to epitomize freshness in North America, and it was ironically struck by "scentsorhip" (153) by a gallery concerned about its effects on health. In the early twentieth century, air conditioning was hailed as a promise of economic betterment. Yet, Michael Rakowitz's prominent solipsistic radiator system is set to keep humidity at a level which is best for the preservation of its steel ductwork but which is detrimental to human comfort. Its heating corollary (paraSITE, 1998) is a social statement against the "homeless-proof" 
policies of Rudolf Giuliani. In both Vaporization (2002) and Air (2003), Teresa Margolles diffused the wastewater of autopsies in a mist that is congruent with the limbo of the newly dead. The sterilized but putrid vapour was inhaled by and shed on the visitors' skin, reintroducing death in today's sanitized interiors. The environmental impracticality of air conditioning is also apparent in the water cycle of Hugh Pocock's Drilling a Well for Water (2003). On the other hand, Dan Peterman tried to seek a technoadapted solution rather than resort to denunciation in Sulfur Cycle (1994). Like "the return of the repressed", Olafur Eliasson's "The weather project" (2003) introduced various climactic conditions indoors, emphatically displaying the technology meant to control it.

In a last chapter, which is midway between a documentary and personal account, involving a complete "embodied experience", and quite different from a classical scholarly article, Gabriel Koureas takes us on a tour of the sensorial impact of the trauma on the polito-graphy of the wounded city of Nicosia. After a flashback of the historical sovereignties, he shows how the hegemonic points of view of the successive maps of the conquerors are revelatory of the will of totalization and control, and their denial of the "other" shows the extent to which they wish to contain this potentially subversive and feared "other". The tour Koureas embarks upon leads him to the two museums and monuments that insist on the traumatic memories and on the unrecognizability of the other community. He then examines how different artists deal with this literal and figurative "Dead zone" splitting the island.

Such a last chapter may surprise in a scholarly edited volume, but its personal investment conveys sensorial feelings that may be lacking in other chapters. Indeed, the rest of the book uses a formal rhetoric which indeed suits academic purposes, but more gusto in the general arguments might have been more adapted to the subjectsensorial impressions. Moreover, smell and hearing are dealt with, but touch receives limited attention, and taste, none at all, it seems-apart from when museums cafés are mentioned! Unfortunately, the book seems to reproduce the visual brainy compartmentalised culture it seeks to denounce. More imaginative a stance has yet to be found to solicit all the reader's senses.

\section{INDEX}

Keywords: holy communion, Holy Ghost, homoeroticism, eating, Nabis, futurism, Tatillismo, Nicosia

Mots-clés: communion, hostie, homoérotisme, Nabis, futurisme, Tatillismo, Nicosie, manger 


\section{AUTHORS}

MURIEL ADRIEN

Maître de conférences

Université Toulouse 2 - Le Mirail

muriel.adrien@univ-tlse2.fr 